\title{
THE S-AUX-O-V-OTHER SYNTAGM IN ATLANTIC ${ }^{*}$
}

\author{
G. Tucker Childs \\ Portland State University
}

\begin{abstract}
As the largest language phylum in the world and the most geographically widespread (Williamson \& Blench 2000), Niger-Congo understandably exhibits some variation at all grammatical levels. Basic word order stands as no exception to this generalization, and there have been partisans for both an SOV and an SVO reconstructed word order. Gensler 1994 attempts to reconcile the two by claiming that neither proposal is correct; he suggests that both SOV and SVO are derived from Proto-Niger-Congo *S-AUX-O-V-Other. Because of the pattern's "quirkiness" (being found virtually nowhere else in the world) and because it is so widely attested in geographically widely separated Niger-Congo languages, the pattern should be reconstructed for all of Niger-Congo. One crucial piece of evidence for this claim comes from the Southern Atlantic language Kisi. This paper explores Kisi's facts in further detail to show how central the structure is to the language. It then expands the investigation to other languages of Atlantic, finding that the pattern is much more widely attested than was previously realized, albeit in an attenuated form. The paper concludes by discussing the significance of the Atlantic facts to Niger-Congo in general.
\end{abstract}

\section{Introduction.}

A number of typologically and genetically unusual structures appear in Kisi, a language belonging to the Southern Branch of Atlantic. The morphosyntactic

* My thanks to the editor and two SAL referees who wished not to remain anonymous, John V. Singler and Orin Gensler, for helping to vastly improve this paper. They are not, of course, to held responsible for ways in which I may have not followed their advice. Abbreviations used in this paper are listed at the end of the article. 
structures common to Niger-Congo are found in Kisi, noun classes and verb extensions; these expected parallels, noted explicitly in Mukarovsky (1958) (following Westermann 1925, 1927), beguiled the former into claiming a genetic relationship between Kisi and Bantu, much closer than that achieved by common membership in Niger-Congo. To be fair, the unexpected patterns treated here may not have appeared in the incomplete data Mukarovsky considered when he made this claim (he had only the field notes of an American anthropologist (Earthy, n.d.) to work with.). One of these unusual structures is the topic of this paper, the syntagm S-AUX-O-V-Other, the "split" or "distributed" predicate.

At the joint WOCAL/ACAL conference in 2003, a workshop was devoted to discussing what was there grandiloquently called "distributed predicate syntax", but here takes the prosaic form of S-AUX-O-V-Other. The word "distributed" may require some explanation, but first the preliminary definitions in (1).

(1) Preliminary definitions (Gensler \& Güldemann 2003)

AUX a closed class of elements expressing inflectional categories to possibly include: Tense, Aspect, Mood, Negation

$\mathrm{V}$ an open class of elements expressing typical verbal semantics (activities, processes, states, etc.) [the lexical verb] ${ }^{1}$

$\mathrm{O}$ a single object [see the qualifications below]

Other $^{2}$ all other sentence augments and adjuncts except $\mathrm{S}, \mathrm{O}$

Gensler's talk at the workshop began by renaming "distributed" "split", and thus a section of his talk dealt with "split predication". As he pointed out, there are many more possible splits. The most obvious is what he called the "syntagmatic" split between the auxiliary and the verb, but there are others, as in (2).

"Split" syntax: S-AUX-O-V-Other (Gensler \& Güldemann 2003)

1. Syntagmatic split:
a. S-AUX-O-Verb-Other (split predicational nucleus $=\{\mathrm{AUX}, \mathrm{V}\})$
b. S-AUX-O-Verb-Other (split set of verbal actants $=\{\mathrm{O}$, Other $\})$

2. Paradigmatic split: "Split in the sense of possible co-occurrence with other construction types, notably, S-(AUX)-V-O (as in 'split ergativity')"

1 The material in square brackets is my own and is meant as a heuristic aid.

${ }^{2}$ The discussion of "Other" does not form part of this paper except with regard to Kisi, primarily because there is so little information in the available sources. 
In Gensler's senses of 'split', then, the language of focus, Kisi, is trebly split, in all the ways given in (2). Along with the first two splits, Kisi features an alternation between S-V-O and S-AUX-O-V word order.

This paper begins by presenting a full characterization of the latter pattern in Kisi, expanding on and updating the original presentation in Childs (1995), as well as squaring it with other patterns in the language. The next step is to look at other Atlantic languages, making reference to what might be called an areal explanation. This explanation proceeds from the contention that the source for this anomalous structure is the Mande languages with which Kisi speakers have been in long and continuous contact (Childs 2002), a superficially plausible explanation, as outlined in the next paragraphs.

Within Niger-Congo, the sub-phyla Kordofanian, Atlantic, Gur, Kru, Kwa, and Benue-Congo are said to be SVO and only Mande is consistently "SMOV" ["M" = "Aux", roughly speaking] (Williamson \& Blench 2000: 39). Thus, Kisi is exceptional with regard to Atlantic and most of the other Niger-Congo phyla. Its widespread S-AUX-O-V-Other word order, however, follows the overwhelmingly consistent pattern in Mande, by whose languages Kisi's speakers are completely surrounded; thus, an areal explanation immediately suggests itself. In Map 1 one can see just how surrounded they are: the Mande languages encircling the Kisi area are preceded with a circled asterisk. One Mande language, Lele, actually shares part of the (northwest) Kisi area.

Kisi has, in fact, a long history of contact with a number of Mande languages; Mande speakers have surrounded, infiltrated, and dominated the Kisi before and ever since the "Mane" invasions of the $16^{\text {th }}$ century (Rodney 1967). Thus, the sociohistorical conditions are right, and the Mande languages with which Kisi has been in contact all have the S-AUX-O-V-Other pattern. Childs (2003b) suggests that this pattern does show some areal distribution in West Africa, as first postulated for other structures in Heine \& Reh (1984).

However, after looking at the languages within Atlantic, that claim must be abandoned, or at least weakened. One reason is that the structure is more widespread in Atlantic than originally thought. This is the conclusion of the survey in sections 2.1 and 2.2. Languages in the southern and northern branches of Atlantic both exhibit the structure, as well as the isolate Bijogo. Secondly, the structure does not appear in circumstances where it might be expected to appear, if the areal explanation were to be valid. Not only is the structure absent in those Atlantic languages which are profoundly influenced by Mande languages, but it is also present in languages uninfluenced by Mande. 
Map 1: Kisi surrounded by Mande

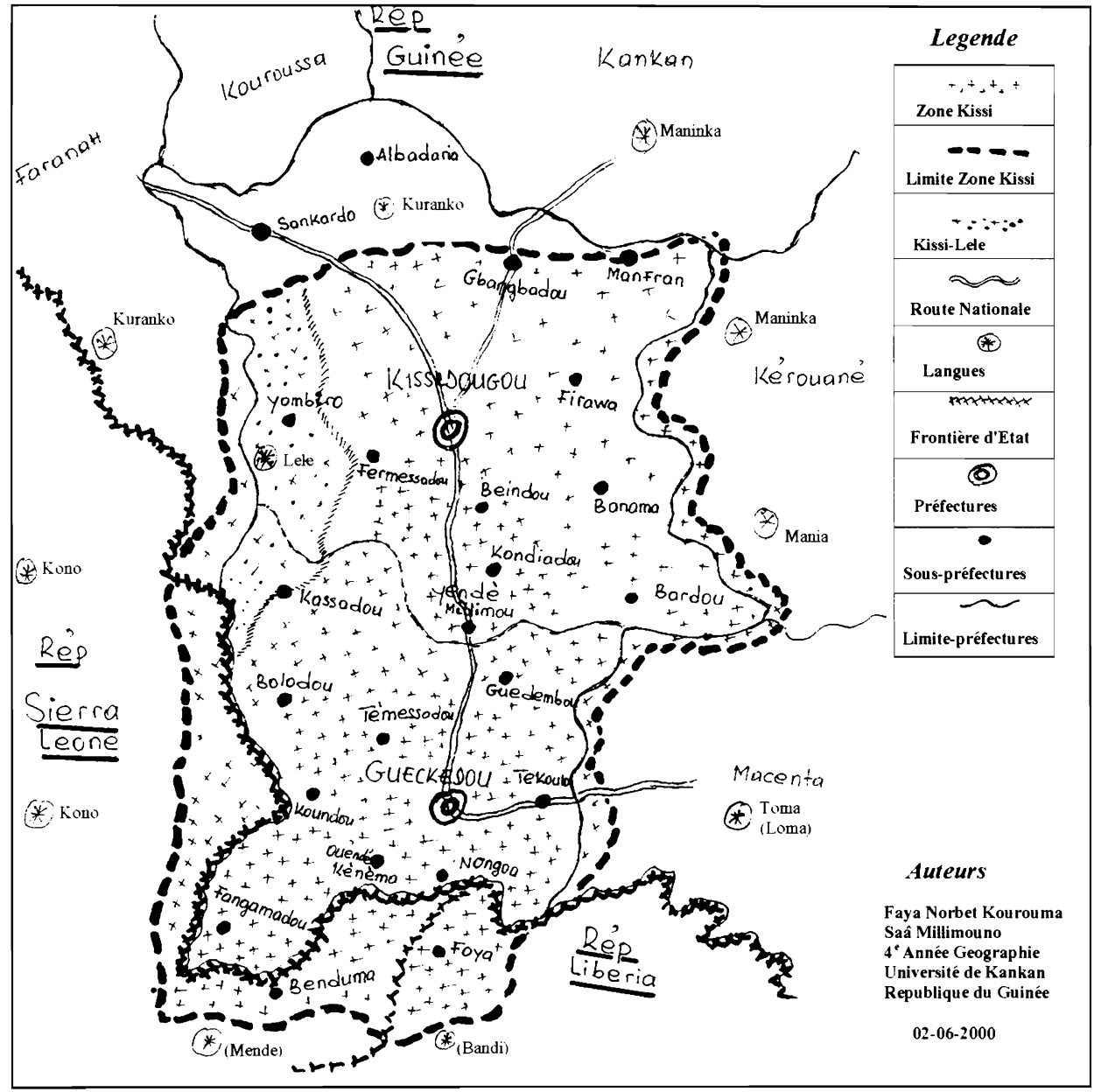

Another reason for rejecting the areal explanation is historical. The Kisi have been surrounded by the Mande only in relatively recent times; the real dominance by Mande speakers took place in the final days of the Mali Empire $\left(16^{\text {th }}\right.$ century on). Finally, as seen in section 2 , the structure is deeply embedded in the grammar and quite productive. With all of these facts in mind, it now seems 
as if only a genetic explanation accounts for what is found in Atlantic, although an areal explanation may be invoked elsewhere in Niger-Congo. ${ }^{3}$

\section{Map 2: Geographical location of the Atlantic languages}

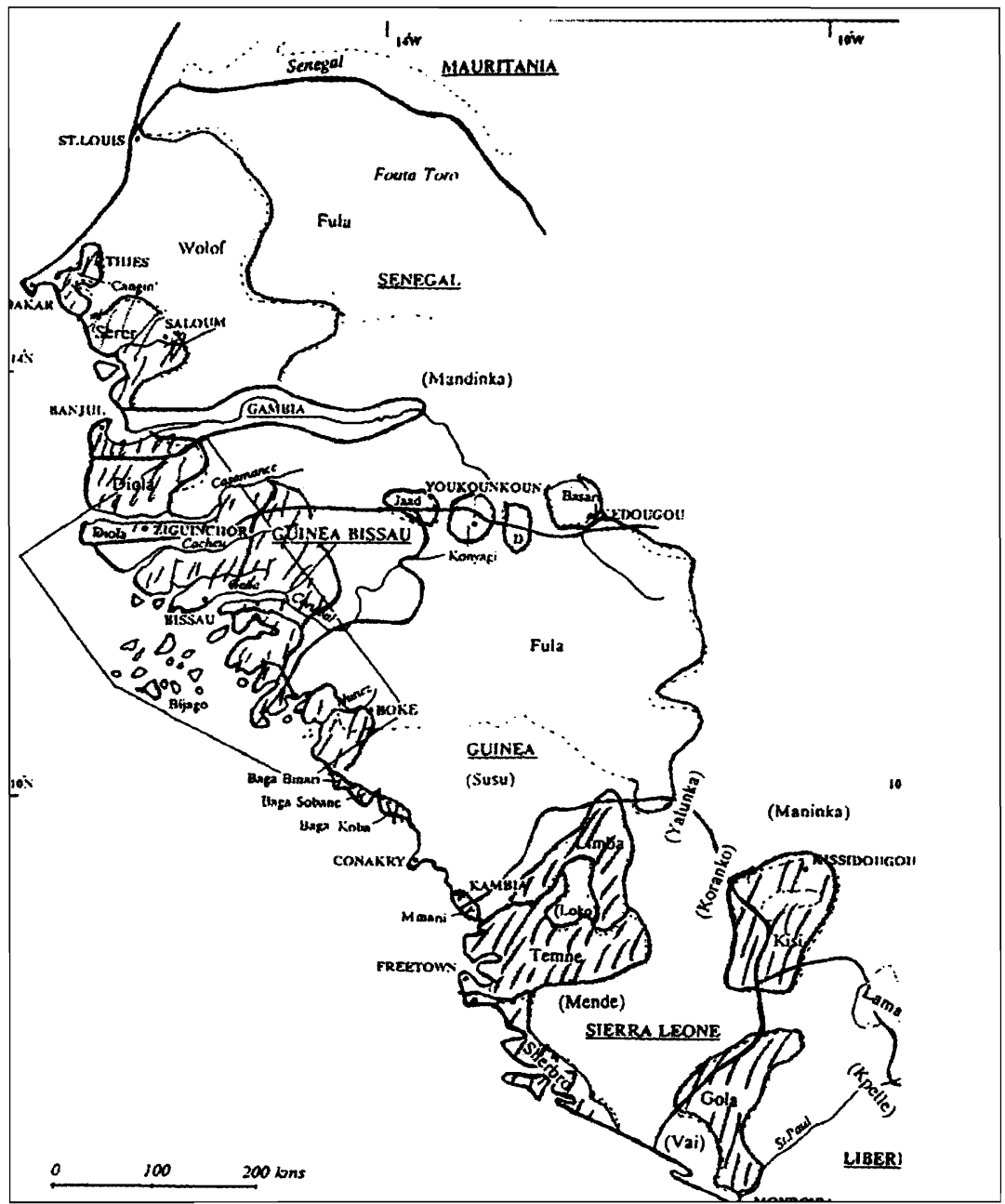

${ }^{3}$ Note that the Fulfulde-speaking territory ("Fula" on the map) extends much further to the east than can be shown on the map. 
The Atlantic Group consists of some fifty languages, many of them well known, e.g., Wolof and Fulfulde, but the majority of them much less widely spoken and threatened by more widely spoken languages, both from within and outside Atlantic. The language group is found in a broad swath along the Atlantic coast from Senegal to Liberia, roughly speaking, and consists of two disparate branches and an isolate. Map 2 shows the Atlantic languages, all but Wolof and Fulfulde with cross-hatching, in a map adapted from Wilson (1989). The Mande languages fill in the rest of the area, and their names are given in parentheses where indicated.

In a paper given at the $31^{\text {st }}$ Colloquium on African Languages and Linguistics (Childs 2001), I raised the question as to why linguists persist in seeing Atlantic as constituting a genetic entity, presumably on a par with other genetic groups within Niger-Congo such as Mande, the group with which it has an ongoing and often intimate relationship (Childs 2000, 2004). In that same paper I tried to show that although the grouping may serve an important referential function, it has no other validity except as an interesting historical object. This claim was not new. As noted many times before, e.g., Wilson (1963), the main reasons for seeing the Atlantic languages as a unity, aside from the typological reasons given above, are that they are not Mande and they are not close to anything else. Nonetheless, the grouping serves as a useful heuristic and will be considered appropriate for the discussion which follows.

With this remark as a caveat, we will proceed. The generally agreed-upon classification of Atlantic appears in Table 1. Languages that appear in boldface are those in which the S-AUX-O-V structure appears $(n=13)$; languages underlined are those in which it does not appear $(n=5)$. Unaltered language names are languages for which the question cannot be answered on the basis of available evidence. 


\section{Table 1 The Atlantic languages classified}

I. Northern Branch $(n=34)$
A. Senegambian languages
1. Fulfulde, Seereer
2. Wolof
B. Cangin: Lehar, Safen, Noon; Ndut, Palor
C. Bak

1. Diola

(1) Bayot-Essin

(2) Diola Proper

(a) Karon, Kwatay

(b) Diola-Fogny, Gusilay, Kasa

(c) Ediamat, Mlomp, Her

2. Manjaku, Mankanya, Papel

3. Balanta

D. Eastern Senegal-Guinea

1. Tanda: Onian, Wamei

2. Biafada, Badyara

3. Buy, Kasanga; Bainouk

E. Nalu: Nalu, Pukur

\section{Bijogo}

III. Southern Branch

\section{A. Mel languages}

1. Temne; Baga Maduri, Baga TJitem, Lonit\}, Baga Koba, Landoma

2. Bulom languages: Kisi; Mani, Sherbro, Krim, Bom

3. Gola

B. Limba

\section{Analysis.}

This section begins by laying out the facts in Kisi, a language used in the proposal found in Gensler (1994) for reconstructing S-AUX-O-V-Other. I then look a little deeper into the Kisi facts to see if there are synchronic traces of an evolutionary cline, fossilized constructions or remnants, in the manner of Greenberg's "processual comparison" (e.g., Greenberg 1969). The point of this analysis is to discover where the structure came from and/or where it is going. Internally no obvious 
trend can be found, but a comparison with other languages shows the pattern to be quite attenuated outside Kisi in different ways in different languages, just as would be expected with an old, well-established structure.

It was originally assumed that the syntagm represented an innovation, possibly an effect of contact with surrounding Mande languages, since much else seems to be borrowed into Kisi (Childs 2002). It turns out that there are parallels, however, to the structure in other nearby related languages, both ones subject to Mande influence, but also ones not subject to such influence. Beyond Kisi's closest relatives the same findings occur, counterevidence to the areal explanation.

Before turning to the facts of Kisi, I need to remark that only one Southern Branch language out of those with grammars extensive enough to qualify for inspection did not have the structure, Baga TJitem of the Baga cluster.

S-AUX-O-V-Other in Kisi. This section discusses examples of the S-AUX-O-VOther syntagm in Kisi. The first pair of examples features clauses with simple verbs, where objects follow verbs.

$\begin{array}{lllllll}\text { S } & \text { V } & \text { o } & \text { S } & \text { V } & \text { o } & \text { o } \\ \text { kèùwó } & \text { lòwá } & \text { sàá } & \text { ò } & \text { ké } & \text { yá } & \text { tòòlúlán } \\ \text { snake } & \text { bite } & \text { Saa } & \text { she } & \text { give } & \text { me } & \text { support } \\ \text { 'The snake bit Saa.' } & & \text { 'She } & \text { gave } & \text { me support.' }\end{array}$

The examples in (4) show the S-AUX-O-V-OTHER syntagm with compound verbs, i.e., verbs with an auxiliary (as opposed to those in (3)). The two sentences (4a) have a single object, and the next two sentences (4b) have double objects.

(4) Clauses with compound verbs: The S-AUX-O-V-OTHER syntagm

\section{a. $\mathbf{S}$ AUX $\mathbf{O}$ V}

fàlà có léénndó yìkpàá

Fallah PROG machete sharpen

'Fallah is sharpening the machete.' ỳ cò bèllôn còùwià we PROG palm-nuts pick 'We are picking the palm nuts.'
b. $\mathbf{S}$
AUX
O
à wá
ndú
O
V
they PROG.PAST him
kòówán
kioó
medicine give
'They were giving him medicine.' 


\begin{tabular}{|c|c|c|c|}
\hline cò & bùngàn & hìndǎn & cùčiyán \\
\hline PROG & area & swollen & oil \\
\hline
\end{tabular}

'He's putting ointment on the boils.'

The examples in (5) illustrate some of the "Other's" prepositional phrases after the lexical verb in (5a) and (5b), a non-object nominal argument with no adposition in (5c); and finally in (5d) another adpositional phrase.

$$
\text { "Other" in Kisi }
$$
a. à cò
bàlóś
á yéélán
they PROG surround with weeping
'They go around weeping.'
b. à cò cùùndǒn lé wáltá ndàlán they PROG praise for work their 'They will praise themselves for their work.'
c. à cò dìnǒn kùndàá they PROG gather group

'They will gather together in a group.'
d. à cò ndú hiwioó ó nè̀ they PROG him accompany to road
'They are accompanying him on the road.'

Although such structures are not common, when a two-argument verb is marked with a valence-increasing extension such as the Benefactive, three arguments can appear between the auxiliary and the verb. I was not able to find such an example with one of the two true auxiliaries, but I did find one with what I call below an "incipient auxiliary", 4 the word for 'go'.

(6) Three objects preceding an (extended) verb

ò kùc yá fàlá mààlón kèlló

he go me Fallah rice give.BEN

'He's gone to offer rice to Fallah for me.' 
The likelihood that three arguments are allowed with true auxiliaries is strengthened by the examples in (7). In each sentence the benefactee $n d u$ ' him', the additional argument allowed by the verb extension, appears inside, between the auxiliary and the verb.

(7)

Arguments before extended verbs
$\begin{array}{lllll}\text { a. ò cò ndú yòmndó hì̀lùlló } \\ \text { he } & \text { PROG } & \text { him tree } & \text { shake.BEN }\end{array}$
b. à cò ndú dìmnndó hìwilló they PROG him word translate.BEN 'They are interpreting for him.'
'He's shaking the tree for him.'

Thus, we have seen that only arguments without an adposition are allowed in the split slot. When a noun is accompanied by an adposition it appears after the verb, as in (8). (Also consider the examples in (5).)

(8) pòó cò hèngínndó á lànò píláá
man

'The man is boasting to someone's wife.'

It is not an absolute prohibition that only unaccompanied NPs can occur within the split predicate, but rather a (statistical) generalization, for there are several other elements that can appear in the slot, most of them particle-like words with meanings close to those often conveyed by inflections, as seen in (9). For example, the word for 'now' in the first sentence conveys a perfect meaning when used with the simple verb forms (see the discussion following example (10)).

(9) Other material within the split predicate

ò cò nîy yá mààlón hùngùlló
he PROG now me rice beat.BEN

'He is beating (my) rice for me.'

ò cò lè hàù kénǒn f̌́ćn màlày wànà cêlén sòlà

he PROG POL today give-MID first before person other get

'Let him give [it] to himself today first before another person gets [it].' 
ò cò yá pò̀ hiùlùlló ó pàngá

he PROG me now wait.BEN to farm

'He is now waiting for me at the farm.'

ò cò láy wèlè hèc̀ndǒy ó kèsú

he PROG them again place to shoulder

'He will again place them on his shoulder.'

Time words such as hà̀ 'today' can appear both within - (10a) — and after the split predicate - (10b). Such words, as opposed to objects, are only optionally present within the split predicate.

(10) Variable syntax: Material within and without the split predicate

a. sókóó cò hàù húnòj herbalist PROG today come

'The herbalist is coming today.'

b. ̀̀ cò làkò hàù yéndèmà ${ }^{5}$

we PROG go today town

'We will be going to Yendema today.'

$$
\begin{array}{llll}
\text { miàllá cò yá hìùlló hàu } & \\
\text { strangers } & \text { PROG me come today }
\end{array}
$$

'Strangers will be coming to me today.'

Thus, a number of elements other than nominal arguments can appear within split predicate constructions. Based on their semantics and their reduced phonological status, such words are "incipient verbal markers", waiting to cliticize leftwards and become (phonologically) part of INFL. Particles such as nî conveying 'perfectivity', the politeness particle $l \grave{\varepsilon}$, and the question particle $y \grave{\varepsilon}$ are clearly phonologically part of words to their left, as discussed in Childs (1995). The other candidate examples are all time words, another category typi-

${ }^{5}$ The town name ý́ndı̀mà has no preposition, following a general prohibition against prepositions before place names. The fact that it cannot appear within the split predicate, despite the fact that it is a nominal argument without a preposition, is likely due to another prohibition against locatives appearing in this environment (see the discussion around example (11)). 
cally marking on verbs crosslinguistically, but not a distinction robustly marked in Kisi, which usually marks only mood and aspect on verbs. Thus, such words could be expanding the set of inflectional contrasts to include more tense distinctions.

It should be noted that locatives are not possible within split predicates, as they are in a few other Atlantic languages, Kru and in some Bantu languages (Chaga, Kinyarwanda) as object pronoun infixes, despite the fact that many are unmarked by an adposition. In Kisi neither locatives nor proper place names are accompanied by an adposition.

(11) Locative arguments not considered objects in Kisi

$\begin{array}{llll}\text { i có làkò fóóyá } & \text { 'I am going to Foya.' } \\ \text { I } & \text { PROG go } & \text { Foya } & \\ \text { *' }_{1} \text { có fóóyá làkò } & \text { 'I am going to Foya.' } \\ \text { I } & \text { PROG Foya go } & \text { gog }\end{array}$

Note how this stands in sharp contrast to the plethora of temporal expressions Kisi allows in the same position.

The next point to be made is that the structure is widespread and productive in Kisi. This is shown in two ways: first of all, by the fact that "incipient" auxiliary verbs follow the same pattern of S-AUX-O-V-Other; secondly, by the fact that the structure is found in embedded clauses and in other sentence types.

"Incipient" auxiliary verbs. In Kisi several otherwise normal (lexical) verbs function identically to auxiliaries. Syntactically, they cause the same inversion of object(s) and verb as do true auxiliaries. When this inversion occurs, (nonsubject) arguments must occur between the auxiliary and verb, and the verbs themselves follow in their non-finite forms, just as with true auxiliaries. Semantically these incipient auxiliaries signal distinctions comparable to inflectional ones but still retain some of their lexical meaning. These verbs otherwise display full verbal syntax and morphology. One such verb is cii 'finish', conveying a 'completive' meaning (cf. Welmers 1973). Note how in (12) the objects, yòmndé in (12a) and fóndàyndáy in (12b), appear before the nonfinite verb forms, lòm ̀̀ and $h \grave{\varepsilon} w \grave{\imath}$, and after the incipient auxiliary, just as would objects with a fully qualified auxiliary. 
(12) Completive cii 'finish'

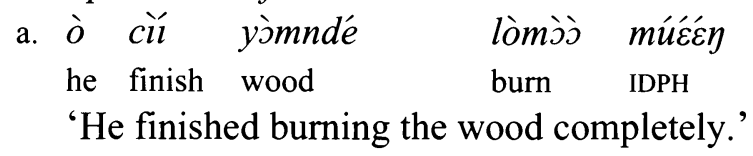

b. ò cù fóndàyndán hèwì

he finish spaces occupy

'He occupied the (empty) spaces.'

The verb cii is in the same position with the same syntax as the auxiliaries co and wa. The change from a verb to an auxiliary is common in African languages, particularly with regard to a verb meaning 'finish' (Heine \& Reh 1984: 38). A "desemanticized"6 "finish' is commonly reduced to an aspect marker, e.g., -isha in Swahili; feni in Liberian English (from English finish (Singler 1999)).

The verb 'have' has a modal meaning, expressing obligation, as illustrated in (13).

(13) tààilán ndân lá nó wànà súéí cùùwó ní bonds these PRO have people palaver bring FOC

'It is these commitments that cause trouble between people.'

ó kòlò̀lán ndân ṇ̌̌ ndá nò já yònùlló ní to drinking this in they have you harm FOC

'Your involvement in drinking means they will harm you.'

Some examples of verbs that form part of the tense-aspect-mood system of Kisi are given in (14). In both cases the verb and its object replicate the OV word order followed by more established auxiliaries. 
(14) Continuative lo 'stay, continue'

í ló kisié pècekùo háa mí cáà

I stay Kisi study until CONJ.1SG know

'I continued to study Kisi until I learned how [to speak it].'

ò cò hùnòò cíóón tòòià̀

he PROG come towns look.at

'He will (come) inspect the towns.'

Examples in (15) show verbs with only their core meaning (less desemanticized), which follow the same syntactic pattern, the verbs 'fail' in the first sentence and 'hurry' in the second. $\begin{array}{lllll}\text { (15) ò dèmál } & \text { sàa } & \text { wàlló tòsàl } & \text { kpôy } \\ \text { he fail } & \text { Saa } & \text { work } & \text { do } & \text { IDPH }\end{array}$

'He failed completely to do the work for Saa.'

yòn wòónndó kéléngá ndú yùùwà ní happen bad hurry him be.old.CS.PL FOC

'Disreputable activities made him age prematurely.'

In all cases these incipient auxiliaries take the same syntax as true auxiliaries. The S-AUX-O-V-Other pattern appears widely even in less grammaticized constructions, comparable to the constructions with real auxiliaries. The pattern is also found in relative clauses, just as in main clauses, as well as in questions and focus constructions, as seen in the following section. Its presence attests further to the importance of the structure.

Alternate word order in other environments. Both word orders (S-V-O and SAUX-O-V) are found in relative clauses, which have been bracketed in the examples. Example (16a) features the AUX-less construction and (16b) shows a relative clause with the auxiliary co. The pronouns kón 'that' (16a) and hóo 'this' (16b) are optional resumptive pronouns, which behave just as would any other pronoun in a similar environment. 
(16) Both orders found in relative clauses
a.

$$
\begin{array}{llll}
\mathbf{S} & \mathbf{V} & \mathbf{O} & \mathbf{O}
\end{array}
$$

fàfálá [s ndá fàfáliál yá kón]-ó kpóú à sòlá lé struggle [ they struggle me that]-REL all they get NEG 'Despite all that struggling that they went through for me, they got nothing out of it.'

b. $\quad$ S AUX O V

wálí [s j̀ cò hóò tòsàá]-ó tàmbà ndóó ké núm tòòulán work [ you PROG this do]-REL Tamba he-IMPF give you support 'Did Tamba give you any help with this job that you are doing?'

The same split occurs in other sentence types with non-basic word order: focus constructions and WH-questions. To the left appear the examples of S-AUX$\mathrm{O}-\mathrm{V}$ in non-basic sentences; to the right are $\mathrm{S}-\mathrm{O}-\mathrm{V}$ versions of the same sentences, i.e., without an auxiliary. The two examples in (17) feature focus constructions; the examples in (17b) show two WH-questions. In the first of the two focus examples in (17a) the verb 'get' (soli) remains in situ because it is the 'sob-

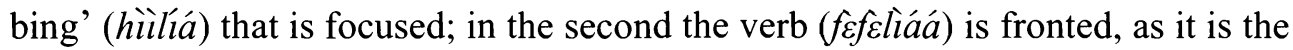
item focused, and thus sentence order is V-S-Aux-O on the surface.

(17) Split word order in non-basic sentences: WH-questions and focus constructions

a.

$$
\text { S AUX O V }
$$

bàà hìlía có núm sòlì lèning ní

whether crying PROG you get inside FOC

'Is it sobbing that will save you from it?'

hìlía sòlì núm

'Sobbing saves you.'

$\begin{array}{llll} & S & A U X & 0\end{array}$

f̂̀fêliaáa ó có bùngàn mùn ní

lingering he PROG portions those FOC

'He's sticking around for those portions.'

ó f́ćf́lìàa bùngàn mùn

'He stays around for those portions.' 
b. $S$ AUX O V

nèćné cò yè mómóó yàù who PROG Q rice cook 'Who is cooking the rice?'

$\mathbf{S}$ lós-kùéć time-where you 'When are you doing the work?' nèćné yàù yè mómó

'Who cooks rice?'

In summary, we see that the "splits" are robustly attested in Kisi. Furthermore, the Kisi evidence furnishes strong support for the idea of the S-AUX-O-VOther syntagm providing a template for "renewal", as argued in Gensler (1994). Incipient auxiliaries easily slot into the position occupied by more prototypical auxiliaries. No other Atlantic language, however, exhibits such robustness in the structure. In the languages discussed below, the distribution of the construction is restricted in some way, and sometimes variable. I first turn to exemplification in other Southern Branch languages and then to the rest of Atlantic.

Two points need to be made before entering the discussion of other Atlantic languages. The first involves an assumption, namely, that morpheme order within a word in one language can be compared to the syntax-level ordering of morphemes in another language where the morphemes are free words, (see Givón 1971). I have made this assumption primarily because many sources are not explicit or are unclear about how or sometimes even where word divisions have been made. In some languages different sources may not conform to each other. To treat only syntactic order would severely compromise the task, despite the potential mismatches between the morphology and syntax. The second prefatory remark is less controversial. For other Atlantic languages "Other" will not be discussed (for reasons given in note 2.) and reference will be made to S-AUX-O-V as the relevant syntagm.

2.1 S-AUX-O-V elsewhere in the Southern Branch. We have seen in Kisi how the word order alternation, the paradigmatic "split" in (2), depends on whether the verb involves an auxiliary, and moreover involves both nouns and pronouns; elsewhere in Atlantic it is only pronouns, with several exceptions, that feature the $\mathrm{S}-\mathrm{AUX}-\mathrm{O}-\mathrm{V}$ order. Furthermore, there is variation on whether all pronouns participate, on whether all auxiliaries condition the shift, and whether auxiliaries are 
even needed at all. The reader may want to refer back to Map 2 and Table 1 during the following discussion.

Mani. The first language is Mani, a language spoken today far away from Kisi in the Samou region of the Guinea and Sierra Leone coasts. It is genetically close to Kisi (both are in the Mel subgroup) and is heavily influenced by Mande, specifically by Soso in Guinea, the language which virtually all ethnic Mani speak, although some ethnic Mani have switched to Temne (Childs, to appear). ${ }^{7}$ Thus, if Mande influence were the crucial factor one would expect the structural split to be even more robustly attested than in Kisi.

Exact parallels to Kisi structures do not exist, as revealed in recent fieldwork $(2000,2004)$ and in the limited literature (Moity 1948, 1957, Mukarovsky 1966), despite the (linguistic) closeness of the two languages. Nonetheless, there are some examples of object pronouns before the lexical verb. In the first example (18a), the object pronoun $m i$ appears before the verb sinc $\dot{\varepsilon}$, and in (18b) the object pronoun hin appears before the lexical verb kámátíl and after the auxiliary $l_{\varepsilon}$. At this point it is uncertain how widespread the phenomenon is; what is certain is that it is no where near as common as in Kisi.

(18) Pronouns before the lexical verb in Mani
a. rànó cé
wò mì s̀̀-ǹ̀
farmer DEF
3SG 1SG clear-BEN
'The farmer cleared (the field) for me.'
b. pàà lì-cé lè hì ká-mátíl
sun NCM-DEF PROG 1PL give-warmth
'The sun is warming us.'

If indeed language contact is the explanation, Mani would be expected to attest the structure more widely. Thus, Mani offers counter-evidence for an areal influence in a language with heavy Mande influence. I now turn to another Mel language, Sherbro, also closely related to Kisi but more closely related to Mani (66\%-69\% on a lexical comparison (Grimes 1996)), where the structure does appear, albeit in a limited way.

${ }^{7}$ On the Sierra Leone side of the former Mani-speaking area, Soso is also used as a primary language but most Mani speakers have switched or are switching to Temne. 
Sherbro. Sherbro is the language most closely related to Kisi and would seem to be the logical place to find evidence that might shed light on the provenance or trajectory of the distributed predicate construction. It thus qualifies on the genetic closeness criterion, but is equivocal on the Mande-influence criterion. Although its speakers are also participating in language shift, the pressure is not from Mande alone (here Mende is the significant language) but also from Temne, another Atlantic language (Iverson \& Cameron 1986: 12-13), where the S-AUX-O$\mathrm{V}$ structure is also found (see the following paragraphs). Interestingly, we find that Sherbro has split word order in much the same way as Kisi, but only with pronouns, as in Mani. In verbal constructions without auxiliaries, the object comes after the verb whether the object is a pronoun or a noun.

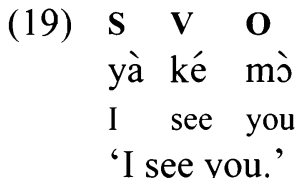
$\begin{array}{lll}\text { S } & \mathbf{V} & \mathbf{O} \\ \text { yà } & \text { kònthì-é } & \text { s’̀k-ś́ }\end{array}$
I catch-FREQ-A ${ }^{8}$ chicken-PL-the
'I caught the chickens.' (Rogers 1967: 140)

But when the verb has an auxiliary, pronouns precede the verb and sometimes even also the auxiliary. The primary or unmarked order is the former, however, SAUX-O-V. Thus, the primary order of S-AUX-O-V parallels the Kisi and Mani situations, while the more marked order does not, showing the intra-language variation we will see elsewhere.

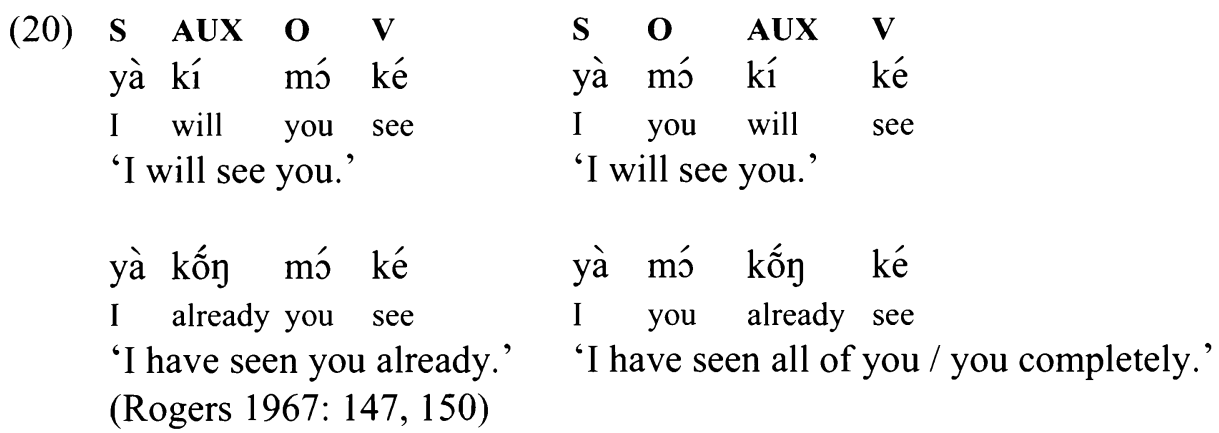

8 "A" is an undefined morpheme. 
There are no alternative orders when sentences are negated. I mention this here because elsewhere in Atlantic the negative behaves as an auxiliary, but here the negative marker is a clitic on the pronominal object, as shown by both sentences in (21).

(21)

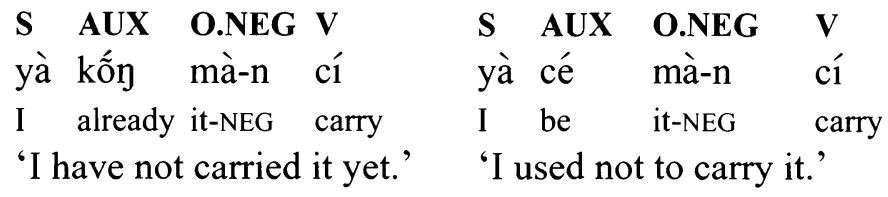

(Rogers 1967: 142, 143)

Full NPs do not appear between the auxiliary and lexical verb but rather after the verb.

(22) yà cé nà kònth sòk-́́
I be recently catch chicken-the
'I was catching the chicken.' (Rogers 1967: 143)

More than one auxiliary can fill the AUX slot; the pronoun will appear after all of them (contrast this with the behavior of the negative marker in (21)).

$\begin{array}{lll}\text { (23) yà ká cè mó ké } & \text { yà bí hầ cé wò ké } \\ \text { I PASt be you see } & \text { I have to be him see } \\ \text { 'I used to see you long ago.' } & \text { 'I will be seeing him.' (Rogers 1967: 130) }\end{array}$

This generalization about pronouns moving to a slot before the verb is not exceptionless. The example in (24) shows a pronoun appearing after a verb with an auxiliary. Rogers makes no comment, stating only, "A noun phrase, locative phrase, or clause follows the verb phrase; a pronoun object is a part of the verb phrase" (emphasis added) (Rogers 1967: 126).

$\begin{array}{llll}\text { S } & \text { AUX } & \mathbf{V} & \text { O } \\ \text { yà } & \text { ká } & \text { kè } & \text { mó } \\ \text { I } & \text { past } & \text { see } & \text { you }\end{array}$

Locative pronouns also appear in the post-auxiliary pre-verbal slot (Rogers 1967: 126). 
In sum, Sherbro does indeed have at least an attenuated form of the SAUX-O-V structure. We should also note that the pattern is not nearly so widespread as it is in Kisi and shows some variation. Sherbro provides equivocal evidence for the areal hypothesis since its speakers are switching to both Mende and Temne.

Temne. Temne belongs to the (internally) closely related (Wilson 1962) Baga sub-group of Mel, to which Baga TSitem also belongs, where the structure surprisingly could not be found (Ganong 1998). Temne is one of the two major languages of Sierra Leone and serves as a second language for many speakers. The influence of Mande, then, would be expected to be fairly minimal if not nonexistent, but the structure is there.

Temne has the S-AUX-O-V structure only variably: when an auxiliary is present and the object is a pronoun, the pronoun can occur both before and after the verb (Wilson 1961). Note how the subject pronoun and the auxiliary form a single word; it is not clear from the source if the two morphemes are ordered within the word (see note 11).

(25) эpo yo ti opo ti yo
Aux-he do it AuX-he it do
'He had done it.' (Wilson 1961: 27)

The next language to be considered, Gola, is less closely related to Kisi than is the Baga sub-group (Wilson 1989), but nonetheless has some S-AUX-O-V constructions, occurring when the objects are pronouns, as in Mani, Sherbro, and Temne.

Gola. The Gola people are located in two small pockets in Liberia, just spilling over into Sierra Leone (Sindlinger \& Seyi 1973). Gola is not part of the Bullom sub-group ( $29 \%$ cognacy) but still part of Mel ( $22 \%$ cognacy, Wilson 1989). Thus Gola is weak on genetic relatedness to Kisi but has been strongly influenced by Mande, particularly by Mende, to which language almost all Sierra Leone speakers have switched (Sindlinger \& Seyi 1973).

As best as can be deduced, Gola features S-AUX-O-V word order, but only when the arguments are pronominal. What is different about Gola is that it involves all verbal constructions, not just ones with auxiliaries, as in Mani. The generalization here is that pronouns always precede the (lexical) verb; this holds 
for indirect and direct objects, both when they occur singly and when they occur together. The examples in (26) show that full NPs are always after the verb.

(26) $\mathrm{S} \quad \mathrm{AUX} \mathbf{V} \quad \mathrm{O}$ wò nan yèmè wonyaan wofelaa ว̀ nan dhènè lejos he PAST see elephant man the PAST buy rice 'He saw an elephant.' 'The man bought rice.'

wò yaà dhìkì̀ ejè̀ $l \varepsilon$

he PROG tie rope the

'He is tying the rope.' (Sindlinger 1975: 2-3)

The examples in (27) show how pronouns appear between the auxiliary and verb.

(27) S AUX O V

wò nan min yèmè wofelaa $j$ nan in dhènè

he PAST me see man the PAST it buy

'He saw me.' 'The man bought it.'

wò yaà in dhikiè

he PROG it tie

'He is tying it.' (Sindlinger 1975: 3-4)

When there are no auxiliaries, pronouns appear before the verb; full NPs appear after.

(28)

$\begin{array}{lllll} & \mathbf{S} & \mathbf{O} & \mathbf{V} & \\ \text { Pronoun object: } & \text { hẽ } \tilde{\varepsilon}, & \text { ka } & \overline{1} & \text { komã } \\ & \text { yes } & \text { I } & \text { it } & \text { hear } \\ & \text { 'Yes, I have heard it.' }\end{array}$

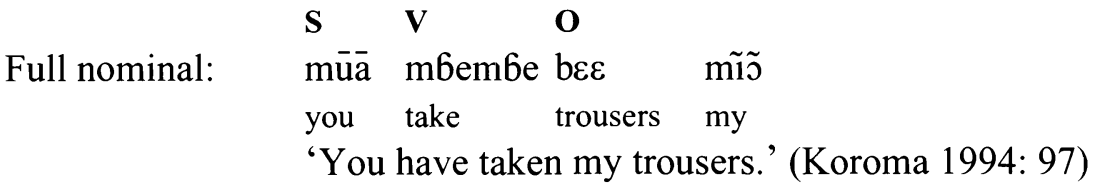

In Gola, then, we have attestations of the construction but only with respect to pronouns. Contrasting with Mani, Sherbro, and Temne, however, Gola features 
pronouns before the verb in all verbal constructions, even when no auxiliary is present.

This consideration of several Southern Branch languages has shown us that the S-AUX-O-V syntagm may not be easily correlated with areal factors, i.e., Mande influence. Although the degree of Mande influence is difficult to gauge precisely, Mani is the language that has been most heavily influenced by Mande and there the syntagm is weakly attested. In Temne, likely the language most impervious to Mande influence, the syntagm has something of the same status. Gola and Sherbro have both been more heavily influenced by Mande than Kisi, but neither one has the robustness of the structure found in Kisi. In the absence of any demonstrable correlation with areal factors, then, a genetic source seems more likely on the basis of Southern Branch evidence.

The next section presents several Northern Branch languages with similar constructions; once again no language allows all NPs between the parts of a split predicate, as does Kisi and no other Southern Branch language. One language comes tantalizingly close, however, in allowing phonologically reduced nouns and a locative in the slot.

2.2 The S-AUX-O-V syntagm elsewhere in Atlantic. The isolate Bijogo, belonging to neither the Southern or the Northern Branch, has the pattern, but in a way slightly different from what has been seen thus far. In several Northern Branch languages, no comparable structures were found: Fulfulde (based on Arnott 1970, Pelletier \& Skinner 1981), Diola-Fogny (Sapir 1965, Hopkins 2003 p.c.) Gusilay (Hopkins 2003 p.c.), and Manjaku (Karlik 1972). But in several others it was found, e.g., Wamei, (Hopkins 2003 p.c.), where it was even more widely distributed than in the Southern Branch.

The isolate Bijogo. As with the Southern Branch it is only the pronouns that appear in the slot created by a split predicate, but here only a subset of the pronouns. Bijogo has a noun class system, as do all Atlantic languages, which overlaps with the set of personal pronouns. It is not all possible pronouns that participate in the process. Only the first and second person personal pronouns regularly appear between AUX and the verb. The $3 \mathrm{SG} /$ class $1^{9}$ (object) pronoun -mo-, and in one

9 Segerer uses the terms "class 1" and "class 2" in a way comparable to the way they are used by Bantuists. These classes thus have predominantly animate referents. 
dialect the 3PL / class 2 pronoun -ma-, sometimes also appear there (Segerer 2002). (In Bijogo classes 1 and 2 correspond to $3 \mathrm{sg}$ and $3 \mathrm{pl}$ personal pronouns.)

\section{Table 2: Bijogo pronouns}

$\begin{array}{llll}\text { 1SG } & \text {-na- } & 1 \mathrm{PL} & \text {-anti- } \\ \text { 2SG } & - \text { am- } & 2 \mathrm{PL} & \text {-anni- } \\ \text { 3SG / Class 1 } & (-\mathrm{mo}-) & 3 \mathrm{PL} / \text { Class 2 } & \text { (-ma-) }\end{array}$

Thus, the order S-AUX-O-V is possible, but only when the "O" is one of the personal pronouns; the structure is variable for classes 1 and 2. The examples in (29) illustrate the pronoun after the aspectual markers and before the main verb.
(29) u-
ba- na- joy
'He will see me.'
cl.1.IMPERF- POT- $1 \mathrm{SGO}-$ see
$\begin{array}{lll}\text { n(a)- } & \text { anti- } & \text { nian } \\ \text { 2PL.PERF- } & \text { 1PLO- } & \text { help }\end{array}$
'You (plural) help us!'

The S-AUX-O-V pattern is found in the Northern Branch, prominently in several languages of the cohesive Cangin sub-group but also in Balanta, a language belonging to the Bak sub-group, and perhaps in a few other places, such as in Biafada, where the discussion of the Northern Branch begins.

Biafada. The S-AUX-O-V syntagm occurs widely in Biafada but is limited to pronominal objects, as in the Southern Branch languages examined above (except Kisi). In Biafada, full NP subjects always come before the auxiliary and full NP objects come after the verb, with or without an auxiliary. Object markers, however, move within the verbal complex and appear after the auxiliary and before the verb: "When a verb stem follows an auxiliary or a modal verb, any object suffix semantically linked with it is affixed to the auxiliary or modal" (Wilson 1993: 82). Thus, when the subject is a full NP and the object is a pronoun, one finds the constituent order of S-AUX-O-V. When the subject is not a full NP, however, the subject marker is generally suffixed to the auxiliary. Thus the order AUX-S-O-V can occur when subject and object are both pronouns, as shown in (30). The object remains, however, between the two parts of the split predicate as in all cases when an auxiliary is present. 
$\begin{array}{lll}\text { (30) AUX } & \text { S O } & \text { V } \\ \text { ro } & \text {-mmana } & \text { re-ä } \\ \text { go } & \text {-3PL+3SGO see-ä } \\ \text { 'They went to see him.' }\end{array}$
AUX AUX SO $\quad$ V
mmən -d -iammä dam-ä
NEG!able -IMPV -3SG+3PLO kill-ä
'He must not be able to kill them.' (Wilson 1993: 82)

Biafada belongs to sub-branch "D" (Eastern Senegal-Guinea) of the Northern Branch (see Table 1). No data was available for sub-branch "E" (comprising the two languages Nalu and Pukur), but for all three of the other sub-branches the SAUX-O-V construction is attested. The next language to be considered, Balanta, comes from the Bak group (sub-branch "C").

Balanta. The facts of Balanta are quite complicated but nonetheless provide some examples of S-AUX-O-V. In Balanta, the S-AUX-O-V construction is obligatory only under restricted circumstances, being limited to object pronouns in negative and subjunctive constructions; it is variable elsewhere. In negative and subjunctive constructions pronominal object markers appear between the negative or subjunctive marker ("AUX") and the verb. I first exemplify the variable situations, since they are relatively straightforward.

With auxiliaries (the term is used loosely) other than the negative and subjunctive, object clitics may appear on the verb stem (first example) or on the auxiliary (second example), the second possibility providing an example of the $\mathrm{S}$ AUX-O-V syntagm.

(31) $\mathrm{s}$

$\begin{array}{llll}\text { S } & \text { AUX } & \text { V } & \text { O } \\ \text { y- } & \text { gaa } & \text { k- } & \text { saf } \\ \text { 1sG.SUB- } & \text { PROG } & \text { CL4- } & \text { writing } \\ \text { S } & \text { AUX } & \text { O } & \text { V } \\ \text { sadio } & \text { gaa } & \text {-ma } & \text { rine } \\ \text { Sadio } & \text { PROG } & \text { 3SG.OBJ } & \text { sleep.with }\end{array}$

$-\mathrm{ma}$

'I am writing it.'

3SG.OBJ

I now turn to the more complicated case of the negative and the subjunctive. 
Negation is marked by consonant alternation and word order changes when objects are pronominal. In addition, a special set of subject prefixes is used with tonal and segmental differences from the "basic" pronouns. The Balanta verb is negated in the Ganja dialect studied by Fudeman ${ }^{10}$ by geminating and devoicing the intial obstruent of the object clitic, if there is one. What is relevant to the discussion here is that instead of the object clitic appearing after the verb, as in (32a), it appears before the verb, albeit geminated and devoiced, producing a sequence reminiscent of S-AUX-O-V.

(32) Balanta (Ganja dialect) negation with object clitics (Fudeman 1999: 81)

$\begin{array}{lll}\text { a. Affirmative bì- } & \text { biifa- baa } \\ & \text { 3PL.SUB- see- } & \text { 3PL.OBJ } \\ & \text { 'They saw them.' } & \end{array}$
$\begin{array}{llll} & \text { S } & \text { AUX.O } & \text { V } \\ \text { b. Negative } & \text { bí- } & \text { ppaa- } & \text { biifa }\end{array}$
3PL.SUB- NEG.3PL.OBJ See
'They didn't see them.'

A slight variation is found in another Ganja dialect. Negation is here signaled by the lengthening of the vowel of the subject prefix and only sometimes gemination of a following consonant. Thus, the subject marker has assumed the function of marking negation ${ }^{11}$, at least some of the time. The example in (33) presents an example where the negation is signalled on the subject and object marker. The constituent order, however, remains S-AUX-O-V.

${ }^{10}$ Fudeman's dialect is Ganja, as is the dialect treated in N'Diaye-Corréard (1970), (1973). Wilson (1961) treats the Kentohe dialect, which Wilson (1989) considers a different language from Ganja, according to Fudeman (1999: 5).

${ }^{11}$ That the subject marker carries distinctions generally associated with AUX is not uncommon in West Africa, e.g., Hausa (Newman 2000), Manjaku (Karlik 1972) and Wolof (below, p. 31); see also the examples for Bijogo and Biafada). Gensler notes in his comments that AUX could be considered "swallowed up" by the subject marker as in, e.g., Mende. 

(33) áa-
mmà-
bāg
3SG.SUB.NEG- NEG.3SG.OBJ carry.under.arm
'He did not carry it under his arm.'
(N’Diaye-Corréard 1973: 182, in Fudeman 1999: 80)

In two other negative constructions we see the object between the two parts of the verb, the "Negative imperfective/future" and negated imperatives.

(34) Negative imperfective/future (Fudeman 1999: 97)
hal á- tim- ba- hur
person 3SG.SUB NEG.IMPF 2PL.OBJ know
'No one will know you.'

Object markers also precede the lexical verb in negative imperatives:

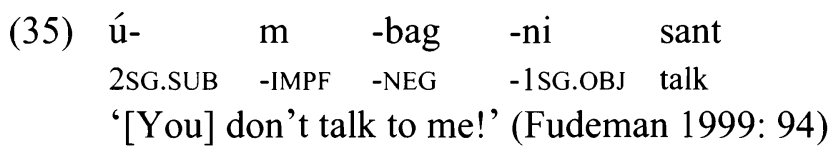

The subjunctive marker has a more phonetically overt form, the "discontinuous morph" $-n a-\eta$, whose first element appears after the subject prefix and before the object marker(s) when present; the second element follows the object marker if present, and the whole complex occurs before the verb stem (Fudeman 1999: 85). When there is no object pronoun, the subjunctive marker is realized as -nay ("SBJC"), as in (36).

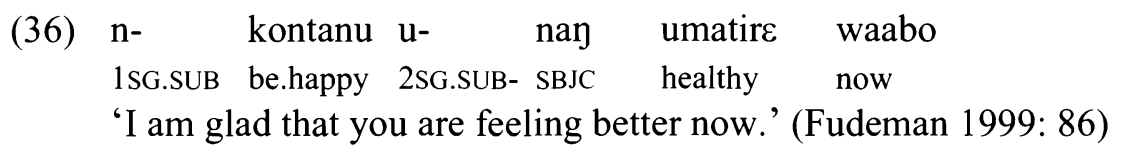

When there are object pronouns, they appear "within" the subjunctive marker, sandwiched between the two parts of the discontinuous subjunctive morpheme, as shown by the examples in (37). Following Fudeman, I have bolded the object markers. Note that there are two objects enclosed within the discontinuous marker in the second example of $(37 b)$. 
(37)

a. $S$ AUX -O- AUX V

à- bin- $t \varepsilon$ sam a- na- $-\mathbf{f i -} \eta \quad$ biifa

3SG.S- come- DIR that 3SG.S SBJC CL5 SBJC see

'He came in order to see it' (e.g., the dog, a member of Class 5)

b.

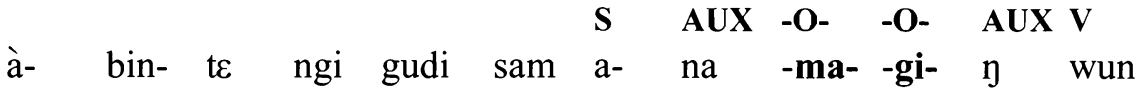
3SG.S- come- DIR with money that 3SG.S SBJC 3SG.OBJ CL2 SBJC give 'He came with money in order to give it to him.'

(Fudeman 1999: 88; cf. Wilson 1961: 154)

Other tense and mood markers, however, appear after the verb, so in some sense AUX is also paradigmatically "split" in the sense of Gensler \& Güldemann 2003. When there are post-verbal auxiliaries, objects occur after the verb before the auxiliaries, the mirror image of the pre-verbal sequence.
(38)
S AUX $\quad$ V $\quad$ O
O AUX AUX
nde a- n- nūm- ma- te mós ...
if 3SG.SUB- IMPF- bring- 3SGO- PAST HYPO
'When he brought her...'
(N’Diaye-Corréard 1970, as cited in Fudeman 1999: 130)

From a functional perspective, pronouns in both environments serve to keep the auxiliary and verb separate.

Cangin: Ndut, Palor, Noon. In the closely related Cangin languages (Ndut, Noon, and Palor are the three (of five) languages discussed here (see Table 1)), the construction is broadly (and more straightforwardly) attested. Recall that Kisi and the other languages discussed thus far all belong to the Southern Branch and levels of cognacy between the two branches fall well below the level needed for establishing a genetic relationship ( $9 \%$ ). Thus, Ndut is only distantly related to Kisi.

Ndut has the basic word order SVO. When both a direct and an indirect object occur as either full NPs or pronouns, the indirect object precedes the direct object. 
a. $\begin{array}{llll}\mathbf{V} & \mathbf{O} & \mathbf{O}\end{array}$

mi on-te binta taangal

I give-PFV Binta candy

'I gave Binta a piece of candy.'

(Morgan 1996: 30-31) b. $\mathbf{S} \mathbf{V} \quad \mathbf{O} \quad \mathbf{O}$

$\mathrm{mi}$ on-te ro ri

I give-PFV $2 \mathrm{so} 3 \mathrm{so}$

'I gave you it.'

When an auxiliary is present, full NPs follow the verb, but pronouns obligatorily appear between the auxiliary and the main verb, between the two parts of the split verb. The examples in (40) show the logical possibilities for verbs with two objects.

(40) Word order when auxiliaries are present in Ndut (Morgan 1996: 31-32)

$\begin{array}{llllll} & \mathbf{S} & \text { AUX } & \mathbf{V} & \mathbf{O} & \mathbf{O} \\ \text { Full NPs } & \text { mi } & \text { mín-éh } & \text { yed } & \text { mariyetu } & \text { montor- } \emptyset \mathbf{a} \\ & \text { I } & \text { can-NEG.HAB leave } & \text { Marietu } & \text { watch-CL.DT } \\ & \text { 'I cannot leave Marietu the watch.' } & \end{array}$

$\begin{array}{lllll} & \text { S-AUX } & \text { O } & \text { V } & \text { O } \\ \text { Pro IO } & \text { m-ay } & \text { rii } & \text { yed } & \text { montor- } \emptyset \mathbf{a} \\ & \text { 1s-FUT } & \text { 3so } & \text { leave } & \text { watch-CL.DT } \\ & \text { 'I will leave her the watch.' } & \end{array}$

$\begin{array}{llllll} & \text { S } & \text { AUX } & \text { O } & \text { V } & \text { O } \\ \text { Pro DO } & \text { mi } & \text { mín-éh } & \text { rii } & \text { yed } & \text { mariyetu } \\ & \text { 1s-FUT can-NEG.HAB } & \text { 3so leave } & \text { Marietu } \\ & \text { 'I cannot leave it to Marietu.' } & \end{array}$

$\begin{array}{llllll} & \mathbf{S} & \mathbf{A U X} & \mathbf{O} & \mathbf{O} & \mathbf{V} \\ \text { Pro IO \& DO } & \text { mi } & \text { mín-éh } & \text { ro } & \text { rii } & \text { yed } \\ & \text { 1s-Fut can-NEG.HAB } & \text { 2so } & \text { 3so leave } & \\ & \text { 'I cannot leave you it.' } & & \end{array}$

In summary, when both direct and indirect objects occur in a clause, a pronoun precedes a full NP, and in clauses with an auxiliary, any object pronouns occur between the auxiliary and main verb.

Note that crucially Ndut has had very little if any contact with Mande languages, isolated as it is in the Thies region of Senegal. Wolof is the most powerful influence, with Fulfulde also having some sway. In addition, Ndut has some 
contact with other related languages of the Cangin Group and is particularly close to Palor (84\% lexical similarity (Williams et al. 1987)), the next language to be discussed. Thus, we have yet another language with S-AUX-O-V and no Mande influence; the areal explanation is again untenable.

Palor. In simple verbal constructions, i.e., those without an auxiliary, Palor features S-V-O word order, as in (41a). When an auxiliary is present, however, objects may occur between the auxiliary and the verb. In the sentences of $(41 \mathrm{~b})$, showing the "imminent negative" (l'imminent négatif), abbreviated here as "IM.NEG", we see S-AUX-O-V constituent order. Both pronouns and full NPs occur within the split predicate. In the examples of (41c), marking 'stative' (état acquis), the verb is reduplicated. The first occurrence is marked for number, tense, and negation, while the second verb receives only the mark of modality, a final $-o$. Because of this uneven distribution of categorial marking and because of the parallel with the examples in $(41 \mathrm{~b})$, where there is no reduplication (AUX comes in the same slot), the first occurrence is interpreted as being more of an auxiliary. The example (41d) comes from the Anterior, also involving verbal reduplication and S-AUX-O-V order.

(41) S-AUX-O-V in Palor (D’Alton 1987: 128)

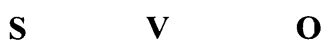

a. tedoxa tente fanfa shepherd treat.PERF cow

'The shepherd treated the cow.'
$\begin{array}{llll}\text { S } & \text { AUX } & \text { O } & \text { V }\end{array}$
b. fun diI ro sex
we IM.NEG you wait
'We are not waiting for you.'

$\begin{array}{llll}\text { S } & \text { AUX } & \text { O } & \text { V } \\ \text { fu } & \text { dII } & \text { payIl } & \text { wo } \\ \text { you } & \text { IM.NEG } & \text { wood } & \text { look.for } \\ \text { 'You are no longer going to get firewood.' }\end{array}$



S AUX O $\quad$ V
c. tedoxa ten fanfa ted-o
shepherd treat.3SG.T cow treat-MOD
'The shepherd treats the cow.'
koyso yoon tuwaab yood-o
child learn French learn-MOD
'My child is learning French.'
d. koyka lewi tal6a?a law-o boy climb-ANT baobab climb-MOD 'The boy was climbing the baobab.'

\begin{abstract}
As can be seen from the examples, both pronominal and nominal objects are inserted within the discontinuous predicate. Note that although the process replicates qualitatively what happens in Kisi, it happens only variably. This is unprecedented in Atlantic outside Kisi.
\end{abstract}

Noon is yet another member of this closely related group and provides a crucial missing type. Generally speaking, full NPs appear after the verb in constructions with AUX, and pronouns move within the predicate, just as we saw in Ndut and Palor. Noon, however, has the important added feature of some nouns being allowed to move inside the complex as well, but crucially, only if they are monosyllabic (my emphasis, Soukka 2000: 210). (42) illustrates where the noun is typically found (after the verb); (42b) shows what happens when the object is a pronoun, and the revealing example in (42c) shows what happens when the noun ('people' 6o') is monosyllabic.

(42) Noon monosyllabic nouns move into preverbal slot (Soukka 2000: 210-11)

a. $\mathbf{S}$ AUX

$\mathrm{V}$

o

beti-faa hay ki-tik cuunoh

woman-DEF will(AUX) INF-cook lunch(OBJ)

'The woman will prepare lunch.'

b. $\mathbf{S}$

$\begin{array}{llll}\mathbf{S} & \mathbf{A U X} & \mathbf{O} & \mathbf{V} \\ \text { ya mi } & \text { wa } & \text { ki-tik } \\ \text { she can } & \text { c1sG } & \text { INF-cook } \\ \text { 'She can prepare it.' }\end{array}$




\begin{tabular}{|c|c|c|c|}
\hline c. $\mathbf{S}$ & $\mathbf{A U X}$ & & \\
\hline fi & joom-oo & $6 o^{\prime}$ & ki-dúk \\
\hline $\begin{array}{l}\text { you(SG) } \\
\text { 'You sh }\end{array}$ & $\begin{array}{l}\text { should-PRES.NEG } \\
\text { ouldn't fool peo }\end{array}$ & $\begin{array}{l}\text { people(OBJ) } \\
\text { ple.' }\end{array}$ & \\
\hline
\end{tabular}

Moreover, it is not just monosyllabic nouns that can move in, but also what Soukka calls "monosyllabic complements", the proximal deictic in (43).

(43) Monosyllabic complements may also split predicates (Soukka 2000: 211)

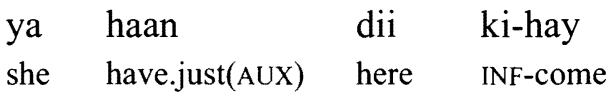
'She has just come here.'

The example in (43), then, shows that it is not that the word for 'people' is becoming grammaticized as an impersonal pronoun, although that may be true as well, but rather that the motivation is phonological. Note that despite its monosyllabicity, the status of the word for 'here' as a locative may be more important in explaining why it is allowed within the split, since in Kru and other languages locatives are licensed to move in.

The last example from Noon shows that the structure is robust, as in Kisi, for it works in constructions with less prototypical auxiliaries as well.
(44) $d_{1}^{\prime}$
jéem-ee-ra
ki-íis
ca
ki-jam
we.EXCL try(AUX)-PAST-PUNCT INF-leave(AUX) OBJ(ClPL) INF-eat
'We tried to stop eating them (e.g., peanuts).' (Soukka 2000: 211)

I now turn to one of the most widely spoken languages, Wolof.

Wolof. In oral presentations of this paper, I stated unequivocally that Wolof did not have the structure, basing myself on Ngom 2003 and several personal communications. Since that time I have (happily) found traces, based on several more personal communications and a closer look at the Ngom grammar. ${ }^{12}$ This trace is

${ }^{12}$ My thanks to Kevin Moore and Fiona McLaughlin for their assistance; they should not be held responsible for any of my misunderstandings. The Wolof facts are quite complex and their interpretation controversial. The final analysis should perhaps await a Wolof specialist. 
important because it means that the syntagm is attested in all major subdivisions of Atlantic (save the Nalu branch consisting of two languages on which there is little literature), some of which may represent isolates (Bijogo) or separate entities (Northern vs. Southern) on a par with other Niger-Congo groups. Thus, the syntagm indeed forms part of Proto-Niger-Congo, as claimed on the basis of other evidence in Gensler (1994).

Wolof is overwhelmingly an AUX-V-O language with a complex set of rules governing subject and object placement (Gensler 2005 p.c.). The few examples below and the surrounding discussion do no justice to that complexity but may offer another avenue of investigation for analysis (see note 12). In the following example, kontine di is considered to be a single "complex verb" and what follows is its complement. Thus, the object precedes the verb and follows what could be interpreted as an (incipient) auxiliary (especially so, in that kontine is a borrowing; languages do not usually borrow auxiliaries, e.g., Thomason \& Kaufman 1988).

Wolof (Munro \& Gaye 1991: x)
mungi kontine di ko lekk
he
continue INC it eat

'He is continuing to eat it.'

That a semblance of the S-AUX-O-V syntagm is found with incipient auxiliaries (and a borrowing) suggest the cognitive reality of the pattern to speakers, much as is the case for speakers of Kisi. More complicated focus constructions illustrate the $\mathrm{V}-\mathrm{O}$ and $\mathrm{O}-\mathrm{V}$ alternations precipitated by the presence of AUX and characteristic of languages with the S-AUX-O-V structure.

For some scholars the focus marker is said to convey aspect and thus would carry the same information usually marked on an auxiliary (McLaughlin 2004 p.c.). The examples in (46) below feature two focus markers occurring after the subject and before the object: NGI (emphasis on the entire sentence) and LA (emphasis on the object). When the object is a full NP, it appears after the verb, as in the first column. If the object is a pronoun it appears before the verb, the pattern we have seen in many other Atlantic languages. 
(46) Woloffocus constructions (Ngom 2003)

$\begin{array}{lll}\text { NGI yeena ngiy jáng wolof } & \text { yeena ngi koy jáng } \\ \text { you FOC study Wolof } & \text { you FOC it study } \\ \text { 'You are studying Wolof.' } & \text { 'You are studying it. }\end{array}$

$\begin{array}{llllllll}\text { LA tey laa wax falu } & \text { tey laa ko } & \text { wax } \\ & \text { I } & \text { FOC tell } & \text { Falu } & \text { I } & \text { FOC him } & \text { tell } \\ \text { 'I told } F a l u \text { today.' } & & \text { 'I told him today.' }\end{array}$

Thus we have relics of S-AUX-O-V attested widely in Wolof, if indeed the focus element is considered AUX. Even without such an interpretation the change in order from $\mathrm{VO}$ to $\mathrm{OV}$ when the focus marker is present is suggestive.

It now remains to put these facts in some kind of order.

\section{Discussion.}

I have not detailed how the present-day Atlantic languages reached their present state. Gensler has indicated some possible trajectories, and the work of Heine and his students, e.g., Heine \& Kuteva (2001), points to many others. Why the structure has disappeared in some languages and is only faintly attested in others may be attributed to its longevity, i.e., simple attrition. In (47) are organized the attested outcomes by type using targets, robustness, and degree of grammaticization as criteria.

(47) Evidence for $* S$-AUX-O-V in Proto-Atlantic

1. The syntactic split persists

a. Affects all NPs and pronouns

i. partially disappears from the syntax, other orders alternate with S-AUX-O-V: Kisi (parallels elsewhere in the grammar, e.g., incipient auxiliaries)

ii. but not in all compound predicates: Palor

b. Affects only pronouns

i. in simple and compound predicates (S-(AUX-)O-V): Gola

ii. and some phonologically similar nouns, phonologization: Noon

iii. only when auxiliaries are present: Temne, Sherbro (with some variation). 
iv. only in some constructions: Balanta (negatives and subjunctives), Biafada (incipient auxiliary constructions)

c. Affects only some pronouns: Bijogo

2. Morphologization

a. Partial: auxiliary complex merges with subject pronouns, auxiliary and verb still separate words: partial in several languages (Temne, Wolof)

b. Complete: Split disappears from the syntax, found at the word level but only with pronouns/object agreement markers, the auxiliary and verb become a single word: Bijogo (not all pronouns)

3. The split disappears, with no traces of the earlier S-AUX-O-V, e.g., Manjaku

Gensler (1994) presents convincing methodological and empirical arguments for the reconstruction of the S-AUX-O-V-Other syntagm as part of NigerCongo, including the "quirk" argument given below, as stated in a later paper (Gensler 1997).

From a purely Niger-Congo-internal perspective, S-AUX-O-V-Other thus appears quite ordinary; it seems merely the natural outcome of routine grammaticization processes. In global perspective, however, it is anything but "natural"... The syntagm is thus a highly marked quirk of Niger-Congo... [p. 68]

... the striking rarity of S-AUX-O-V-Other outside of Niger-Congo makes this syntagm a prime candidate for attribution to the protolanguage... [p. 91]

Quirky it is not, however, in Niger-Congo. Similar structures are found throughout Niger-Congo, as Gensler \& Güldemann (2003) mention, and the many papers given at WOCAL/ACAL (2003) attest. It is featured throughout in Mande (Kastenholz 2003), a language family that branched off from the Niger-Congo stock at about the same time as Atlantic (Williamson \& Blench 2000). It is also found prominently in Kru, e.g., Marchese (1989). Marchese notes that basic Kru word order is SVO in unmarked utterances, but when an auxiliary is present, the word order changes to S-AUX-O-(O-)V, exactly as in Kisi. I direct readers to Gensler (1994) for full details, as well as to Gensler (1997), a review of Claudi (1993), in which he argues against the syntagm as being the product of grammaticization but rather for the syntagm as being the source of the multiple word orders found in Niger Congo. The evidence presented here corroborates his claim 
that the pattern should be reconstructed, and at the same time undercuts the claim that the phenomenon is areal.

To claim that the structure is an innovation seems wrong for a number of reasons, most of them presented convincingly by Gensler. On the basis of the evidence adduced here, it is difficult to explain its many instantiations as due to multiple innovations. If indeed it were an innovation it would be a very old one indeed. Surely it seems more economical and plausible to posit the structure as an old and established one that has suffered some attrition. A more cogent argument would involve the presence of full nouns in the split predicate as an innovation, and I have suggested above how a phonological explanation is plausible for at least Atlantic. But when the Atlantic facts are stacked up against those of NigerCongo in general, the structure's presence is overwhelmingly attested and will probably be found elsewhere as studies broaden and deepen.

\section{Conclusion.}

The evidence from Songhai (Heath 1999a, 1999b) and elsewhere (Gensler 1994) suggests that the S-(AUX-)O-V construction may spread by contact. But because the construction is present in Atlantic and in other branches, it must be reconstructed for Atlantic and likely for all of Niger-Congo since Atlantic is one of the earliest branchings off the Niger-Congo stock. Songhai shows only what is possible, not what has happened in all cases. Local areal explanations seem possible; even for Kisi one could see the influence of Mande as reinforcing the structure, not allowing it to weaken to just pronouns as so commonly happens elsewhere.

That the construction appears in both the Southern and the Northern Branches of Atlantic (and in the isolate Bijogo) is extremely strong evidence that we must reconstruct the syntagm for all of Niger-Congo, for the two branches likely constitute separate groups (e.g., Wilson 1989, Childs 2001). In preserving the older system, that is, in requiring not just pronouns but also full NPs between the auxiliary and the verb, Kisi is more conservative than the other languages. Although this paper contributes little to claims for the genetic unity of Atlantic, it strengthens Gensler's claim for reconstructing the syntagm for Niger-Congo (even more so if Atlantic is broken up); it also affirms Atlantic's membership, if not exact place, within Niger-Congo.

As may have been noticed by the paucity of data on some languages, other Atlantic languages need additional study. Further work, then, will involve both deepening and broadening the sample considered. The in-depth analysis that was possible for Kisi should be extended to other Atlantic languages, and the overall 
analysis itself should be extended to all languages in the group. Unfortunately not all Atlantic languages have the necessary documentation, and some of the Atlantic languages may disappear before they can be adequately described (Childs 2003a). Thus, there is some urgency to the task.

With a broader investigation, one could not only reconstruct the structure for Atlantic as a whole, but also establish grammaticization chains, as discussed in section 3. At this point it seems likely that the latter task is the more formidable since most of the evidence illustrates how the variable structure has become attenuated.

As a final word, I would like to underscore what has been said about allowing for variation. Linguists (comparative and otherwise) should tolerate and even embrace some variation in their reconstructions, as has been pointed out many times, e.g. Guy (to appear), as well as by Gensler (1994), (1997), both of whom try to dispel the notion that we should see grammars as monolithic. Heuristically valuable as the construct of a monolithic grammar is, such an assumption may constrain our investigations and prevent us from seeing the organic richness of language.

\section{Abbreviations}

1so First singular object pronoun

2so Second singular object

pronoun

3so Third singular object pronoun

AUX Auxiliary

C1SG Class 1 singular

C2SG Class 2 singular

CL.DT Classifier-determiner combination

FOC Focus marker

HAB Habitual

IMPERF Imperfect (inaccompli)
INF Infinitive marker

n.d. no date

NEG Negative marker

O Object

OBJ Object

PFV Perfective verbal marker

PL Plural

POT Potential (virtuel)

POL Politeness particle

PROG Progressive

Q Question particle

$\mathrm{S} \quad$ Subject

SG Singular

V Verb 


\section{REFERENCES}

Arnott, D. W. 1970. The Nominal and Verbal Systems of Fula. Oxford: Clarendon Press.

Childs, G. Tucker. 1995. A Grammar of Kisi: A Southern Atlantic Language. Berlin and New York: Mouton de Gruyter.

Childs, G. Tucker. 2000. "The Atlantic and Mande groups of Niger-Congo: A study in contrasts, a study in interaction". International Symposium: Areal Typology of West African Languages. Paper presented at Leipzig: Institut für Afrikanistik, University of Leipzig and Max Plank Institute.

Childs, G. Tucker. 2001. "What's so Atlantic about Atlantic?" Leiden: Paper delivered at the Colloquium on African Languages and Linguistics, Leiden University.

Childs, G. Tucker. 2002. "Borrowings into Kisi as evidence of Mande expansionism and influence". Journal of West African Languages 29: 81-120.

Childs, G. Tucker. 2003a. "Language death within Atlantic: Survival strategies and language change". East Brunswick, NJ: Paper delivered at WOCAL 4 / ACAL34, Rutgers University.

Childs, G. Tucker. 2003b. An Introduction to African Languages. Amsterdam and Philadelphia: John Benjamins.

Childs, G. Tucker. 2004. "The Atlantic and Mande groups of Niger-Congo: A study in contrasts, a study in interaction". Journal of West African Languages 30:29-40.

Childs, G. Tucker. to appear. "Language contact and language death: The sound system of Mmani". Proceedings of ACAL 32 (March 22-25, 2001; University of California, Berkeley), ed. by Ian Maddieson. Trenton, NJ and Asmara, Eritrea: Africa World Press, Inc.

Claudi, Ulrike. 1993. Die Stellung von Verb und Objekt in Niger-KongoSprachen: Ein Beitrag zur Rekonstruktion historischer Syntax. Afrikanistische Monographien I. Köln: Institut für Afrikanistik, Universität zu Köln. 
D’Alton, Paula. 1987. Le palor: Esquisse phonologique et grammaticale d'une langue cangin du Sénégal. Paris: Editions du CNRS.

Earthy, E. Dora. n.d. Field notes. Collected during a brief stay among the Kisi, 1933-34. Madison, WI: Department of African Languages and Literature, University of Wisconsin MS.

Fudeman, Kirsten Anne. 1999. Topics in the morphology and syntax of Balanta, an Atlantic language of Senegal. Ithaca: Cornell University, Doctoral dissertation.

Ganong, Tina Weller. 1998. Features of Baga morphology, syntax, and narrative discourse. Arlington: University of Texas, M.A. thesis.

Gensler, Orin D. 1994. On reconstructing the syntagm "S Aux O V" to ProtoNiger-Congo. Proceedings of the 20th annual meeting of the Berkeley Linguistics Society (Special Session on African Historical Linguistics), ed. by K.E. Moore, David A. Peterson, and C. Wentum. Berkeley, CA: Berkeley Linguistics Society. Pp 1-20.

Gensler, Orin D. 1997. "Grammaticalization, typology, and Niger-Congo word order: Progress on a still unresolved problem" (Review article: Ulrike Claudi: Die Stellung von Verb und Objekt in Niger-Kongo-Sprachen: Ein Beitrag zur Rekonstruktion historischer Syntax, 1993). Journal of African Languages and Linguistics 18: 57-91.

Gensler, Orin D., \& Tom Güldemann. 2003. "S-Aux-O-V-Other in Africa: Typological and areal perspective". New Brunswick, NJ: Paper delivered at WOCAL 4 / ACAL34, Rutgers University.

Givón, Talmy. 1971. "Historical syntax and synchronic morphology: An archaelogist's field trip". Proceedings of the Seventh Regional Meeting of the Chicago Linguistics Society. Chicago: Chicago Linguistics Society. Pp. 394415

Greenberg, Joseph H. 1969. "Some methods of dynamic comparison in linguistics". Substance and Structure in Language, ed. by Jaan Puhvel. Berkeley and Los Angeles: University of California Press. Pp. 147-203 
Grimes, Barbara F. 1996. Ethnologue (13th ed.). Dallas: Summer Institute of Linguistics.

Guy, Gregory R. to appear. Language Variation and Linguistic Theory. London: Blackwell.

Heath, Jeffrey. 1999a. A Grammar of Koyraboro (Koroboro) Senni, the Songhay of Gao, Mali. Köln: Rüdiger Köppe Verlag.

Heath, Jeffrey. 1999b. A Grammar of Koyra Chiini, The Songhay of Timbuktu. Berlin and New York: Mouton de Gruyter.

Heine, Bernd. 1993. Auxiliaries: Cognitive Sources and Grammaticalization. New York: Oxford University Press.

Heine, Bernd \& Mechthild Reh. 1984. Grammaticalization and Reanalysis in African Languages. Hamburg: Helmut Buske Verlag.

Heine, Bernd \& Tania Kuteva. 2001. World Lexicon of Grammaticalization. Cambridge: Cambridge University Press.

Heine, Bernd, Ulrike Claudi, \& Friederike Hünnemeyer. 1991. Grammaticalization: A Conceptual Framework. Chicago: University of Chicago Press.

Iverson, Janelle \& Barbara Cameron. 1986. A Sociolinguistic Survey of the Bullom Languages of Sierra Leone. Freetown, Sierra Leone: Institute for Sierra Leonean Languages.

Karlik, Jan. 1972. A Manjako Grammar with Special Reference to the Nominal Group. London: School of Oriental and African Studies, University of London, Doctoral dissertation.

Kastenholz, Raimund. 2003. "Distributed predicative syntax in Western Mande: an overview". New Brunswick, NJ: Paper delivered at WOCAL 4 / ACAL34, Rutgers University.

Koroma, Regine Fachner. 1994. Die Morphosyntax des Gola. Köln: Institut für Afrikanistik, Universität zu Köln. 
Marchese, Lynell. 1989. "Kru”. The Niger-Congo Languages, ed. by John Bendor-Samuel. Lanham, MD and London: University Press of America. Pp. 119-139

Moity, Marcel. 1948. Étude sur la langue mmani. Dakar: L'Institut Français d'Afrique Noire.

Moity, Marcel. 1957. "Notes sur les mani (Guinée Française)". Bulletin de l'Institut Français d'Afrique Noire 19: 302-307.

Morgan, Daniel Ray. 1996. Overview of grammatical structures of Ndut: A Cangin language of Senegal. Arlington: University of Texas, M.A Thesis.

Mukarovsky, Hans G. 1958. Kisi und Bantu. Archiv für Völkerkunde 13: 132-173.

Mukarovsky, Hans G. 1966. Sherbro, Mmani und die westguineische Sprachgruppe. Vienna.

Munro, Pamela \& Dieynaba Gaye. 1991. Ay Baati Wolof: A Wolof Dictionary. UCLA Occasional Papers in Linguistics 9. Los Angeles: Department of Linguistics, University of California.

N'Diaye-Corréard, Geneviève. 1970. "Études fca ou balante (dialecte ganja)". Biblioteque de la Société pour l'Étude des langues africaines 17.

N'Diaye-Corréard, Geneviève. 1973. "Notes sur le verb fca". Annales de la faculté des lettres et sciences humaines, Université de Dakar: 179-192.

Newman, Paul. 2000. The Hausa Language. New Haven and London: Yale University Press.

Ngom, Fallou. 2003. Wolof. München: Lincom Europa.

Pelletier, Corinne A. \& A. Neil Skinner. 1981. Adamawa Fulfulde, an Introductory Course. Madison, WI: African Studies Program, University of Wisconsin.

Rodney, Walter. 1967. "A reconsideration of the Mane invasions of Sierra Leone". Journal of African History 8: 219-246. 
Rogers, Henry E. 1967. The phonology and morphology of Sherbro. New Haven: Yale University, Doctoral dissertation.

Sapir, J. David. 1965. A Grammar of Diola-Fogny. Cambridge: Cambridge University Press.

Segerer, Guillaume. 2002. La langue Bijogo de Bubaque (Guinée Bissau). Louvain and Paris: Peeters.

Sindlinger, Daniel. 1975. A Preliminary Grammar of the Gola Language. Monrovia: Institute for Liberian Languages.

Sindlinger, Daniel \& Sano Seyi. 1973. A Survey of the Gola Language. Monrovia: Institute for Liberian Languages.

Singler, John Victor. 1999. "On the marking of temporal sequencing in Vernacular Liberian English". Creole Genesis, Attitudes, and Discourse, Studies Celebrating Charlene J. Sato, ed. by John R. Rickford \& Suzanne Romaine. Amsterdam: John Benjamins. Pp. 337-351.

Soukka, Maria. 2000. A Descriptive Grammar of Noon, a Cangin Language of Senegal. München: Lincom Europa.

Thomason, Sarah G. \& Terrence Kaufman. 1988. Language Contact, Creolization, and Genetic Linguistics. Berkeley and Los Angeles: University of California Press.

Welmers, William E. 1973. African Language Structures. Los Angeles and Berkeley: University of California Press.

Westermann, Diedrich. 1925. "Nominalklassen in westafrikanischen Klassensprachen und in Bantusprachen". Mitteilungen des Seminars für Orientalische Sprachwissen 38: 1-52.

Westermann, Diedrich. 1927. Die Westlichen Sudansprachen und ihre Beziehungen zum Bantu. Beiheft, Mitteilungen des Seminars für orientalische Sprachen 29. 
Williams, Gordon, Jo-Lynn Eller, Steve Baughman, Elizabeth Masland, Sue Goddard, Sharon Rand \& Sara Williams. 1987. Enquête sociolinguistique sur les langues cangin de la région de Thiès au Sénégal. Dakar: Société International de Linguistique.

Williamson, Kay \& Roger Blench. 2000. "Niger-Congo". African Languages: An Introduction, ed. by Bernd Heine \& Derek Nurse. Cambridge: Cambridge University Press. Pp. 11-42.

Wilson, W. A. A. 1961. An Outline of the Temne Language. London: School of Oriental and African Studies, University of London.

Wilson, W. A. A. 1961. "Outline of the Balanta language". African Language Studies 2: 139-168.

Wilson, W. A. A. 1962. "Temne, Landuma, and the Baga languages". Sierra Leone Language Review 1: 27-38.

Wilson, W. A. A. 1963. "Diola et langues de Guinée". Les classes nominales et leurs fonctions dans le groupe sénégalo-guinéen ou ouest-atlantique (Actes du 2ème Colloque International de Linguistique Négro-Africaine), ed. by Serge Sauvageot. Dakar: West African Languages Survey, Université de Dakar. P. 280-292.

Wilson, W. A. A. 1989. "Atlantic". The Niger-Congo Languages, ed. by John Bendor-Samuel. Lanham, MD and London: University Press of America. Pp. 81-104.

Wilson, W. A. A. 1993. "An outline description of Biafada". Journal of West African Languages 23: 59-90.

Department of Applied Linguistics

Portland State University

P.O. Box 751

Portland, OR 97207-0751

childst@pdx.edu [received July 5, 2004

accepted December 31, 2004] 